\title{
Fatty acid profile, phenolic compounds and potential antioxidant activity of fresh and cooked Massaman curry paste
}

\author{
Preeya Dat-arun $^{1 *}$, Korawan Chakree ${ }^{1}$, Sukanya Settaraksa² \\ ${ }^{1}$ Interdisciplinary Graduate School of Nutraceutical and Functional Food (IGS-NFF), Prince \\ of Songkla University, Hat Yai, Songkhla 90110, Thailand; ${ }^{2}$ The Herbal Medicinal Product \\ Research and Development Center, Rangsit Univesity, Pathum Thani 12000, Thailand
}

Corresponding author: Preeya Dat-arun, PhD, Interdisciplinary Graduate School of Nutraceutical and Functional Food (IGS-NFF), Prince of Songkla University, Hat Yai, Songkhla 90110, Thailand

Submission Date: August $1^{\text {st }}$, 2019. Acceptance Date: August $28^{\text {th }}$, 2019. Publication Date: July $31^{\text {st }}, 2019$.

Citation: Dat-arun P., Chakree K., Settaraksa S. Fatty acid profile, phenolic compounds and potential antioxidant activity of fresh and cooked Massaman curry paste. Functional Foods in Health and Disease 2019; 9(8): 543-557. DOI: https://doi.org/10.31989/ffhd.v9i8.644

\begin{abstract}
Background: The fresh herbs and spices used in Thai food are what make Thai cuisine unique. Some of these herbs and spices have been scientifically studied for health benefits. However, there is limited evidence for cooked food.
\end{abstract}

Objective: To determine proximate composition, fatty acid profile, phenolic and flavonoid contents and antioxidant activity of fresh Massaman curry paste (MCP) and cooked Massaman curry including beef and chicken Massaman curry (BMC and CMC, respectively).

Methods: The chemical composition and fatty acid profile of freeze-dried samples were analyzed. Food samples were extracted by three solvents: water, absolute methanol or ethanol. The total phenolic and flavonoid contents (TPC, TFC, respectively) of the extracts were measured spectrophotometrically and identified through high performance liquid chromatography (HPLC). The antioxidant activities of extracts were evaluated by 2,2dyphenyl-1-picrylhydrazyl (DPPH) scavenging and ferric reducing antioxidant power (FRAP) assays.

Results: Carbohydrate, protein, and fat were the main components of all sample studies. Chicken Massaman curry (CMC) contained highest fat and energy contents. Fatty acid profile of CMC showed high content of lauric acid $(9460 \mathrm{mg} / 100 \mathrm{~g})$, oleic acid $(6050 \mathrm{mg} / 100 \mathrm{~g})$ and palmitic acid (4220 mg/100 g). MCP showed high content of linoleic acid (213.70 mg/100 g) and palmitic acid $(195.71 \mathrm{mg} / 100 \mathrm{~g})$. Methanol extract of MCP showed the highest content of TPC (1.076 $\pm 0.013 \mathrm{mg}$ gallic acid equivalent (GAE)/100g crude extract), TFC $(27.10 \pm 0.31$ $\mathrm{mg}$ CE/ $100 \mathrm{~g}$ crude extract $)$ and antioxidant activity by FRAP assay $(0.311 \pm 0.002 \mathrm{mg}$ 
Trolox $/ 100 \mathrm{~g}$ crude extract). While ethanol extract of MCP showed the highest activity of $\mathrm{DPPH}$ at value as $11.81 \pm 0.06 \mathrm{mg} \mathrm{GAE} / 100 \mathrm{~g}$ crude extract, following by methanol extract of MCP $(11.02 \pm 0.05 \mathrm{mg}$ GAE$/ 100 \mathrm{~g}$ crude extract $)$. Cooked Massaman curry including BMC and CMC showed low content of TPC and TFC and antioxidant than fresh MCP. Ferulic acid was the main phenolic acid in these samples which was the highest in methanol extract, followed by ethanol and then water extraction. After cooking process, some activities of food were altered.

Conclusion: The results of this study suggest that fresh Massamun curry paste and cooked Massuman curry in ready-to-eat foods could potentially show antioxidant activity. It provided that the health benefits from plants source still remained in the products after cooking process.

Keywords: Thai food, Massaman curry, Antioxidant activity, Fatty acid profile, Phenolic compounds

\section{BACKGROUND}

The famous reputation of Thai food about the flavor and meticulous preparation is well known internationally for over decade. Thai dishes were valued not only the taste but also its health benefits, using the folk knowledge to create healthy and delicious food [1]. About Thai curry such as Tom-Yum, Red or Massaman curry and Green curry has gained popularity dishes [2]. Especially, Massaman curry, was recognized to be the number one most delicious food in the world, based on 50 popular food surveys by Cable News Network [3].

The major ingredients of Massaman curry paste including garlic, shallot, guajillo chili, lemon grass, galangal, coraninder seed, cinnamon, kaffir lime peel and shrimp paste. Garlic and shallot have been known as a grate antibacterial [4], antidiabetic, hypocholesterolemic, antifungal, antiparasitic, antiviral activities and cancer preventive agent [5, 6]. Moreover, other ingredients are effective in several activities such as guajillo chili: antioxidants, antiinflammatory, antidiabetic, antihypertensive, anti-mutagenic and chemo preventive properties [7]; galangal: antiallergic, antidermatophytic, antimicrobial, antiviral, anticancer, antiinflammatory, hypolipidaemic, immune-stimulating activities, gastroprotective and cardiovascular and related effect [8]. Coraninder seed or Coriandrum sativum L., its main bioactive is essential oil, fatty acids, tocol, sterol and carotenoids and its biological activities is antimicrobial and antioxidant [9]. Cinnamon, this spice has been found to have strong antioxidant, antibacterial, antipyretic and anti-inflammatory properties and to use for the treatment of cardiovascular diseases, chronic gastrointestinal and gynecological disorders in oriental herbal medicine [10]. For essential oil, from lemon grass, it is mainly comprised of citral which exhibited a broad antifungal property [2].

Currently there is some research about the health properties of curry paste such as yellow curry, red curry and green curry. But there is no data about the health effect of the Massaman curry which has different components from other curry and may result in different health effects. Therefore, the researchers were interested in studying the effect of bioactive compounds extracts, including the amount and types of fat composition, from fresh and cooked Massaman curry on health properties. But not only this information will be scientific evidence of the health benefits of popular Thai food, they also can be the needs of consumers who are aware of health, especially for global consumers and also are helpful in publicize 
Thai healthy food which should be useful in terms of international marketing. The aims of this study was to determine the chemical composition, fatty acids profile, antioxidant activity and identify some types of bioactive in fresh and cooked Massaman curry extracts.

\section{MATERIALS AND METHODS}

\section{Raw materials}

Massaman curry paste consists of $4.88 \%$ coraninder seed (Coriandrum sativum), $2.09 \%$ caraway (Ocimum gratissimum L.), 2.09\% cloves (Syzygium aromaticum L. Merrill and Perry), $2.09 \%$ cardamom seed (Amomum testaceum Ridl), 3.48\% cinnamon (Cinnamomum bejolghota Sweet), 1.39\% mace (Myristica fragrans Houtt.), $13.94 \%$ guajillo chili (Capsicum annuиm), 1.74\% salt (sodium chloride), 2.09\% white pepper (Piper nigrum), 6.97\% galangal (Alpinia galangal Linn), $10.45 \%$ lemon grass (Cymbopogon citratus), $3.48 \%$ kaffir lime peel (Citrus hystrix DC), 27.87\% garlic (Allium sativum), 13.94\% shallot (Allium ascalonicum), and $3.48 \%$ shrimp paste was collected from local market in Hat-Yai, Songkhla, Thailand.

Generally, beef or chicken is used in the preparation of Massaman curry, so two type of Massaman curry were prepared included beef and chicken Massaman curries. These were composed of $500 \mathrm{~g}$ beef or chicken meat, $200 \mathrm{~g}$ of Massaman curry paste, 6 cups of coconut milk, $300 \mathrm{~g}$ of potatoes, $200 \mathrm{~g}$ of onion, $50 \mathrm{~g}$ of roasted peanuts, $10 \mathrm{~g}$ of roasted Siam cardamoms, 8 table spoon of tamarind juice, $100 \mathrm{~g}$ of palm sugar and $20 \mathrm{~g}$ of sodium chloride.

\section{Sample preparation}

The preparation of curry was conducted by adapting the process used by Royal Thai Cuisine (2006) [11]. To prepare the Massaman curry, herbs and spices (coraninder seed, caraway, cloves, cardamom seed, cinnamon stick and mace) were individually roasted in a pan over low heat until fragrant about 15 min then were finely ground with a blender machine. Chilies and salt were added followed by the addition of white pepper, galangal, lemongrass, kaffir lime peel, garlics, and shallots into a fine paste. Finally, shrimp paste and the ground spice were added properly. The curry was kept at $-20{ }^{\circ} \mathrm{C}$ for further study. To make the curry, beef, chicken, and other ingredients including onion, tamarind juice, potato, and peanut were prepared. The food recipe was obtained from Thai cooking specialists. One kg of curry paste and ready-to-eat prepared food were blended (Panasonic Blender MX 151 SP, Thailand) and freeze-dried under the condition as followed; 0.055 mbar, $12 \mathrm{~h}$, at $-40{ }^{\circ} \mathrm{C}$ (Dura Dry, Dura Freeze Dryer, Canada). The dry food was milled to a powder at 3s (Super Blender, AIKO, China), then the powder was stored in plastic bottles at $-20^{\circ} \mathrm{C}$ until used.

\section{Proximate composition analysis}

The proximate analysis of food was determined according to AOAC [12] procedures and included the following: ash (AOAC method 920.153); moisture (AOAC method 925.45); protein (AOAC method 981.10); fat (AOAC method 948.15). However, carbohydrate was calculated.

\section{Fatty acids composition}

Fatty acids from Massaman curry paste, beef Massaman curry, and chicken Massaman curry were detected as their methyl esters (FAME's) according to Department of Medical Science 
and National Bureau of Agricultural Commodity and Food Standards [13]. Separation of FAME was operated by gas chromatography (Hewlett Packard 6850A) equipped with capillary column, flexible fused silica, $25 \mathrm{~m}$ and 0.2-0.35 mm i.d. A flame-ionization detector was used and helium was used as a carrier gas. Results were expressed as fatty acids composition per $100 \mathrm{~g}$ food.

\section{Sample extraction}

The extraction was conducted by adapting the method used by Do et al [14]. In brief, samples were extracted by three solvents: 100\% methanol, 100\% ethanol and water at room temperature. Extracting ratio of sample to solvent was 1:6. The mixture was homogenized and shacked at $1000 \mathrm{rpm} / \mathrm{min}$ for $1 \mathrm{~h}$. The supernatant was filtered through filter paper, and then evaporated by rotary evaporator, freeze-dried and preserved in brown bottles at $-20{ }^{\circ} \mathrm{C}$ for further analysis.

\section{Determination of total phenolic content (TPC)}

Total phenolic content (TPC) was determined using Folin-Catiocalteau method adapted from Slinkard and Singleton [15]. Briefly, the food extracts were diluted with distilled water at concentrations of $0.1,0.5,1,2,3,4,5 \mathrm{mg} / \mathrm{ml}$. A volume of $12.5 \mu 1$ of the extract from all concentrations and standard solutions (containing 5, 10, 25, 50, 100, 150, and $200 \mu \mathrm{g} / \mathrm{ml}$ of gallic acid in distilled water) were individually subjected into 96-well plate, $12.5 \mu 1$ of Folin Catechau reagent was added to each well and left for 6 min. Afterwards, $125 \mu 1$ of $\mathrm{Na}_{2} \mathrm{CO}_{3}$ solution (7\% w/v in distilled water) and $100 \mu \mathrm{l}$ of distilled water were added. The mixture was incubated for $90 \mathrm{~min}$ in the darkness and the absorbance was measured at $760 \mathrm{~nm}$ using the microplate reader (Bio-TeK PowerWave XS, USA). The results were expressed as mg of gallic acid equivalents (GAE) per $100 \mathrm{~g}$ dry weight.

\section{Determination of total flavonoid contents (TFC)}

Total flavonoid content (TFC) was measured by $\mathrm{AlCl}_{3}$ assay using catechin as reference compound [16]. Briefly, $125 \mu \mathrm{l}$ of the extract and $75 \mu \mathrm{l}$ of $5 \% \mathrm{NaNO}_{2}$ were mixed in 96-well plate. The mixture solution was allowed to stand for $6 \mathrm{~min}$ at ambient temperature and then $150 \mu \mathrm{l}$ of $10 \% \mathrm{AlCl}_{3}$ was added. After $5 \mathrm{~min}, 750 \mu \mathrm{l}$ of $\mathrm{NaOH}(1 \mathrm{M})$ was added and incubated for $5 \mathrm{~min}$ again. The final volume of the mixture was adjusted to $2500 \mu \mathrm{l}$ with distilled water. The mixture was allowed to stand for $15 \mathrm{~min}$ and absorbance was determined at $510 \mathrm{~nm}$. The TFC results were calibrated with a standard curve of Catechin and expressed as Catechin Equivalent (mg CE per 100g dry crude extract).

\section{Antioxidant activities}

\section{DPPH radical scavenging activity assay}

DPPH (2,2-Diphenyl-1-picryl hydrazyl) radical scavenging activity was measured using the modified method of Bran-Williams et al [17]. One hundred $\mu \mathrm{l}$ of the extraction sample and gallic acid standard solutions $(2-10 \mu \mathrm{g} / \mathrm{ml})$ were individually placed in a 96-well microtiter plate. Then $100 \mu$ l of DPPH solution $(0.2 \mathrm{mM}$ in ethanol) was added. The mixture was left at 
room temperature for $30 \mathrm{~min}$ in darkness and the absorbance was measured at $517 \mathrm{~nm}$ using the microplate reader (BioTeK PowerWave XS, USA). The activity was reported as $\mathrm{mg}$ Catechin equivalent (mg CE per $100 \mathrm{~g}$ dry crude extract).

\section{Ferric Reducing Antioxidant Power (FRAP)}

The FRAP assay was determined according to the method of Benzie and Strain [18]. The FRAP solution was freshly prepared by mixing $300 \mathrm{mM}$ acetate buffer (pH 3.6), $10 \mathrm{mM} \mathrm{2,} \mathrm{4,}$ 6-tripyridyl-s-triazine (TPTZ) solution in $40 \mathrm{mM} \mathrm{HCl}$, and $20 \mathrm{mM} \mathrm{FeCl} 3.6 \mathrm{H}_{2} \mathrm{O}$. TPTZ solution $(2.5 \mathrm{ml})$, and $\mathrm{FeCl}_{3} .6 \mathrm{H}_{2} \mathrm{O}$ solution $(2.5 \mathrm{ml})$ were then mixed and incubated at $37^{\circ} \mathrm{C}$ for $30 \mathrm{~min}$ in a warm water bath prior to use (FRAP solution). The food extract samples were diluted with distilled water to $10,15,20,25,30,35,40 \mathrm{mg} / \mathrm{ml}$. Thirty $\mu \mathrm{l}$ each of these diluted food extracts and thirty $\mu \mathrm{l}$ of Trolox standard solutions $(5,10,15,20,25,30 \mathrm{mg} / \mathrm{ml})$ in ethanol were placed in a 96-well micro-titer plate. Then FRAP solution $(270 \mu \mathrm{l})$ was added to both food extracts and standard wells, kept for $30 \mathrm{~min}$ in darkness, and assayed in triplicate. In this reaction, ferric-tripyridyltriazine $\left(\mathrm{Fe}^{3+}-\mathrm{TPTZ}\right)$ complex is reduced from ferric (yellow) to ferrous (blue) form. Development of ferrous tripyridyltriazine complex was measured by absorbance at $595 \mathrm{~nm}$ using a microplate reader (Microplate reader, Biotek, Power wave X, Winooski, USA). The results were expressed as mg Trolox per 100g dry crude extract.

\section{Identification of phenolic compounds by High Performance Liquid Chromatography (HPLC)}

Phenolic acid standards were consisted of gallic acid, protocatechuic acid, $\rho$-coumaric acid, chlorogenic acid, vanillic acid, catechin, ferulic, rutin, cinnamic, quercetin, caffeic acid and syringic acid. The standard solutions were performed by dissolving $0.01 \mathrm{~g}$ of each in $10 \mathrm{ml}$ distilled water. Working solution was made to $20-200 \mu \mathrm{g} / \mathrm{ml}$. Massaman curry paste, beef Massaman curry and chicken Massaman curry crude extracts $(0.02 \mathrm{~g})$ were solubilized in 2 $\mathrm{ml}$ water. The standard and sample solutions were filtered through $0.2 \mu \mathrm{m}$ Nylon-syringe filter and the mobile phase were degassed before the injection of the solutions.

\section{HPLC condition}

HPLC analysis was carried out using an Agilent 1200 series (Agilent 1200, Waldbronn, Germany). The separation was carried out using Eclipse XDB-C18 (250 mm $\times 4.6 \mathrm{~mm}$ i.d., 5 $\mu \mathrm{m}$, Agilent, Santa Clara, CA, USA). The mobile phase consisted of $1 \%$ formic acid in water (A) and methanol (B) at a flow rate $0.8 \mathrm{ml} / \mathrm{min}$. The mobile phase was performed consecutively in a linear gradient as follows: $0 \mathrm{~min}(100 \% \mathrm{~A}) ; 0-10 \mathrm{~min}(90 \% \mathrm{~A}) ; 10-20 \mathrm{~min}$ (75\% A); $20-30 \min (40 \% \mathrm{~A}) ; 30-40 \mathrm{~min}$ (30\% A). The wavelengths were detected at 254, 280 and $325 \mathrm{~nm}$. The column temperature was controlled at $25^{\circ} \mathrm{C}$ and the injection volume was kept at $10 \mu \mathrm{l}$ for each of the sample solutions.

\section{Statistical analysis}

All analyses were carried out in triplicates and reported as means \pm standard deviation. Data were analyzed by analysis of variance (ANOVA) and statistical significance with Duncan's multiple range test $(\mathrm{P}<0.05)$ using SPSS (version 14.0). 


\section{RESULTS AND DISCUSSION}

\section{Proximate analysis}

The results of proximate analysis of Massamun curry paste (MCP), beef Massaman curry (BMC) and chicken Massaman curry (CMC) are presented in Table 1. It is noticeable that the highest amount of ash, moisture and carbohydrate belonged to MCP showed values of 10.10 $\mathrm{g} / 100 \mathrm{~g}, 7.91 \mathrm{~g} / 100 \mathrm{~g}$, and $63.32 \mathrm{~g} / 100 \mathrm{~g}$. While fat and energy in the crude extract were the highest in CMC which recorded values of $31.93 \mathrm{~g} / 100 \mathrm{~g}$ and $534.57 \mathrm{~g} / 100 \mathrm{~g}$, respectively. However, protein content was the highest in BMC and recorded $38.84 \mathrm{~g} / 100 \mathrm{~g}$. Moreover, beef and chicken Massaman curry shared a similar pattern in most approximate analysis.

From the proximate analysis conducted, carbohydrate content in the samples was calculated using the formula [100\%-moisture-ash-fat-protein]. Carbohydrate content was the highest in MCP (63.32\%), followed by CMC (50.39\%) and BMC (42.17\%). Carbohydrate is also known as monosaccharides, disaccharide, and polysaccharides. However, polysaccharides are the main type of carbohydrate in this study which included digested and non-digested (dietary fiber) polysaccharide by human enzymes. The results showed that mixture of herbs and spices showed the highest content of digested and non-digested polysaccharide. While a high content of carbohydrate was found in curry paste other researchers found that some of Thai curry paste such as Thai red curry paste significantly reduces blood glucose, serum malonaldehyde in diabetic group of rats received curry paste compared to the control [19]. Moreover, when mixed curry pastes with other protein source in whole dish such as MCP and CMC, the macronutrient including protein, carbohydrate, and fats content was appropriate for human requirement [20].

Table 1 Proximate composition of different Massaman Curry per $100 \mathrm{~g}$ edible portion.

\begin{tabular}{lccc}
\hline Parameters $(\mathbf{g} / \mathbf{1 0 0} \mathbf{g})$ & MCP & BMC & CMC \\
\hline Ash $(\mathrm{g})$ & 10.10 & 6.25 & 5.75 \\
Moisture $(\mathrm{g})$ & 7.91 & 0.01 & 0.57 \\
Protein $(\mathrm{g})$ & 17.94 & 38.08 & 11.32 \\
Crude fat (g) & 0.73 & 13.49 & 31.97 \\
Carbohydrate (g) & 63.32 & 42.17 & 50.39 \\
Energy (Kcal) & 327.96 & 442.41 & 534.57 \\
\hline
\end{tabular}

MCP; Massaman curry paste, BMC; beef Massaman curry; CMC; chicken Massaman curry

\section{Fatty acid compositions}

Massaman curry is the most delicious Thai food in the world, surveyed by Cable News Network [3]. They contained plenty of herbs and spices and high contents of coconut milk. Coconut milk is an important ingredient of Thai curry. It is an oil-in-water emulsion pressed from the solid endosperm of coconut [21]. Coconut milk is serves as a natural solvent during 
food preparation by extracting both polar and non-polar compounds from various herbs and spices in Thai curry paste [22]. However, health conscious people are discouraged from consuming coconut milk due to its higher content of high saturated fatty acid. The amount of fatty acid composition in MCP, BMC, and CMC is presented in Table 2.

Table 2. Fatty acid composition of different Massaman curry by gas chromatography (GC, g/100 g)

\begin{tabular}{|c|c|c|c|}
\hline Fatty acid composition & MCP & $\begin{array}{c}\text { BMC } \\
(\mathrm{mg} / 100 \mathrm{~g})\end{array}$ & $\mathrm{CMC}$ \\
\hline Butyric acid (C4:0) & 0.00 & 0.00 & 0.00 \\
\hline Caproic acid (C6:0) & 0.00 & 30.00 & 70.00 \\
\hline Caprylic acid (C8:0) & 0.00 & 530.00 & 1250.00 \\
\hline Capric acid (C10) & 0.00 & 510.00 & 1160.00 \\
\hline Undecanoic acid (C11:0) & 0.00 & 0.00 & 0.00 \\
\hline Lauric acid (C12:0) & 0.00 & 4180.00 & 9460.00 \\
\hline Tridecanoic acid (C13:0) & 0.00 & 0.00 & 0.00 \\
\hline Myristic acid (C14:0) & 19.75 & 1260.00 & 2920.00 \\
\hline Myristoleic acid (C14:1) & 0.00 & 0.00 & 0.00 \\
\hline Pentadecanoic acid (C15:0) & 0.00 & 0.00 & 0.00 \\
\hline Cis-10-Pentadecanoic acid (C15:1n10) & 0.00 & 0.00 & 0.00 \\
\hline Palmitic acid (C16:0) & 195.71 & 1440.00 & 4220.00 \\
\hline Palmitoleic acid (C16:1n7) & 0.00 & 0.00 & 460.00 \\
\hline Heptadecanoic acid (C17:0) & 0.00 & 0.00 & 0.00 \\
\hline Cis-10- Heptadecanoic acid (C17:1n10) & 0.00 & 0.00 & 0.00 \\
\hline Stearic acid (C18:0) & 27.45 & 600.00 & 1180.00 \\
\hline Elaidic acid (C18:1n9t) & 0.00 & 0.00 & 0.00 \\
\hline Oleic acid (C18: $\ln 9 \mathrm{c})$ & 172.70 & 2250.00 & 6050.00 \\
\hline Linolelaidic acid (C18:2n6t) & 0.00 & 0.00 & 0.00 \\
\hline Linoleic acid (C18:2n6) & 213.70 & 1570.00 & 2540.00 \\
\hline Gamma-Linolenic acid (C18:3n6) & 0.00 & 0.00 & 0.00 \\
\hline Alpha Linolenic acid (C18:3n3) & 59.51 & 0.00 & 0.00 \\
\hline Arachidic acid (C20:0) & 0.00 & 0.00 & 0.00 \\
\hline cis-11-Eicosenoic acid (C20:2n6) & 0.00 & 0.00 & 0.00 \\
\hline cis-11,14-Eicosadienoic acid (C20:2n6) & 0.00 & 0.00 & 0.00 \\
\hline Heneicosanoic acid (C21:0) & 0.00 & 0.00 & 0.00 \\
\hline Cis-8,11,14-Eicosatrienoic acid (C20:3n6) & 0.00 & 0.00 & 0.00 \\
\hline Arachidonic acid (C20:4n6) & 0.00 & 0.00 & 0.00 \\
\hline Cis-11,14,17-Eicosatrienoic acid (C20:3n3) & 0.00 & 0.00 & 0.00 \\
\hline Behenic acid (C22:0) & 0.00 & 0.00 & 0.00 \\
\hline cis-5,8,11,14,17-Eicosapentaenoic acid; EPA (C20:5n3) & 0.00 & 0.00 & 0.00 \\
\hline Erucic acid (C22:1n9) & 0.00 & 0.00 & 0.00 \\
\hline Cis-13,16-Docosadienoic acid (C22:2) & 0.00 & 0.00 & 0.00 \\
\hline Tricosanoic acid (C23:0) & 0.00 & 0.00 & 0.00 \\
\hline
\end{tabular}

The MCP, BMC, and CMC recorded fatty acid composition at values ranged from 19.75 to $213.70,30.00$ to 4180.00 and 1160 to $9460.00 \mathrm{mg} / 100 \mathrm{~g}$, respectively. The data also revealed that palmitic acid, oleic acid, linoleic acid, stearic acid, alpha linolenic acid and 
myristic acid were found in MCP, BMC and CMP, which are the major fatty acids observed in all the samples as reported in most plant. However, high content of palmitic acid was found in MCP, this type of fat was decreasing in cooked Massaman. Furthermore, oleic acid can reduce blood pressure, increase fat burning and may prevent type 2 diabetes [23]. While linoleic acid can be used to reduce blood cholesterol and lower risk of coronary heart disease [24]. Alpha-linolenic acid was found only in MCP because it is rich in vegetable oil, seeds, nuts and some vegetables which are known to be the dietary sources of alpha-linolenic acid [25]. Linoleic acid and alpha-linolenic acid are known as essential fatty acids for humans, which the human body cannot synthesize on its own [26]. Lauric acid was found only in $\mathrm{BMC}$ and CMC due to their content of coconut milk. Perera et al report that dominant saturated fatty acid in coconut milk is lauric acid and it accounts for half of the total saturated fatty acids [27]. Moreover, stearic acid was the most in CMC (1180 mg/100 g) of fatty acid in sample, same as found in Capsicum spp [28]. This fatty acid might be taken from Capsicum annuum. The current results showed that the major fatty acid in MCP were linoleic, palmitic, oleic, alpha-linolenic acid, stearic, and myristic acids.

\section{Total phenolic and total flavonoid contents}

The results of total phenolic contents (TPC) and total flavonoid contents (TFC) of Massaman curry paste (MCP) and ready-to-eat, Massaman curry including beef Massaman Curry (BMC) and chicken Massaman Curry (CMC) extracted by different solvents (methanol, ethanol and water) are presented in Figure 1.

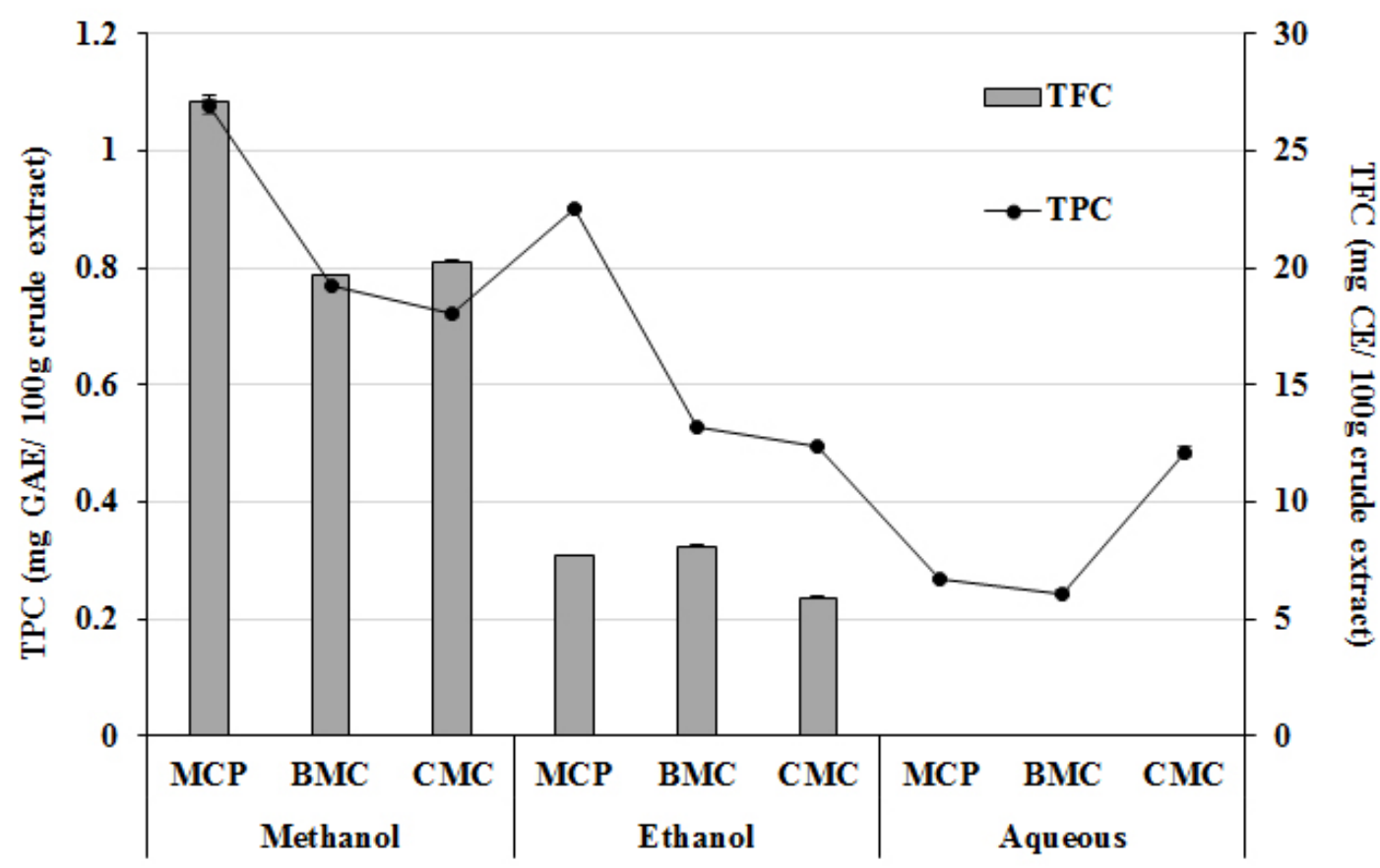

Extract condition

Figure 1. TPC and TFC of different Thai Massaman curry using methanol, ethanol and aqueous extraction. All experiments were performed in triplicate. GAE = gallic acid equivalent, $\mathrm{CE}=$ catechin equivalent, $\mathrm{MCP}=$ Massaman Curry Paste, $\mathrm{BMC}=$ Beef Massaman Curry and $\mathrm{CMC}=$ Chicken Massaman Curry. 
The TPC of various solvent extracts distinctly varied and ranged from $0.244 \pm 0.005$ to $1.076 \pm 0.013 \mathrm{mg} \mathrm{GAE} / 100 \mathrm{~g}$ crude extract. The TPC in MCP, BMC, and CMC extracted with methanol, ethanol, and water showed values ranged from $0.721 \pm 0.005$ to $1.076 \pm$ $0.0131,0.494 \pm 0.00$ to $0.902 \pm 0.003$ and $0.244 \pm 0.005$ to $0.486 \pm 0.008 \mathrm{mg} \mathrm{GAE} / 100 \mathrm{~g}$ crude extract respectively. Methanol solvent could result in the highest amount of TPC, followed by ethanol then water. According to the results of TPC for each sample, it was found that the methanol extract of MCP contained consistently the highest of TPC (1.076 \pm $0.013 \mathrm{mg}$ GAE$/ 100 \mathrm{~g}$ crude extract), followed by those in ethanol $(0.902 \pm 0.003 \mathrm{mg}$ $\mathrm{GAE} / 100 \mathrm{~g}$ crude extract). For cooked samples, BMC and CMC also showed the highest TPC in methanol extracted compared with ethanol and aqueous extracted. However, it was found that the highest TPC in aqueous solutions was found in CMP, followed by MCP and BMC. Total flavonoid contents (TFC) were ranged from $19.70 \pm 0.03$ to $27.10 \pm 0.31 \mathrm{mg}$ $\mathrm{GAE} / 100 \mathrm{~g}$ and $5.88 \pm 0.09$ to $7.71 \pm 0.05 \mathrm{mg} \mathrm{GAE} / 100 \mathrm{~g}$ in methanol and ethanol, respectively. The highest value of TFC was recorded in methanol extract, followed by ethanol. It was observed that TFC in the methanol extract shown to be more than two times when comparing with the ethanol extracts. Unfortunately, TFC could not detect in the aqueous extracted.

The efficiency of bioactive compounds extraction has been reported to be affected by several factors, including the chemical nature of phytochemicals, the extraction method used, the sample particle size, the solvent used, as well as the presence of interfering substances [29]. Under the same extraction temperature and time, solvent and composition of the sample are known as the most important parameters [30]. In the current work, fresh MCP and readyto-eat Massaman curry including BMC and CMC were extracted by using methanol, ethanol and water. The effect of solvents on TPC was observed to be similar to that on TFC. The highest TPC and TFC were found in methanol, followed by those in ethanol extract, while the TPC and TFC of the water extracts is significantly less than that of other solvents $(p<$ 0.05). The difference observed in the phenolic content of these extracts can be attributed to the nature of the biochemical structure of the extracted solvent and the chemical properties of the phenolic compounds available [31]. It may also be caused by the possible complex formation of some phenolic compounds in the extract that are soluble in methanol and ethanol. These phenolic compounds may possess more phenol groups or have higher molecular weights than the phenolics in the water extract [30]. The results of this study are in agreement with Settharaksa et al [32] and Turkmen et al [33] who found that the content of phenolic and flavonoid varied in different solvents. These authors also reported that solvents with different polarity (ethanol and water) have played an important role on polyphenol content. This observation is also in line with those reported by Sepahpour et al [34] who showed that the phenolic content of turmeric extracted with $80 \%$ acetone, $80 \%$ ethanol, $80 \%$ methanol and cold water were respectively 221.7, 172.1, 90.1 and $3.8 \mathrm{mg}$ GAE/g of freezedried crude extract. Base on the results of TPC and TFC, the best extracting solvent was methanol.

\section{Antioxidant activity}

Antioxidant activity in methanol, ethanol, and aqueous extract from MCP, BMC, and CMC as determined by DPPH radical scavenging and Ferric Reducing Antioxidant Power (FRAP) were shown in Figure 2. DPPH radical scavenging activity was found only in methanol and ethanol extraction in MCP. Ethanol extract of MCP was higher than methanol extraction and 
the recorded values were $11.81 \pm 0.06$ and $11.02 \pm 0.05 \mathrm{mg}$ GAE/ $100 \mathrm{~g}$ dry crude extract, respectively. However, the radical scavenging properties in BMC and CMC using the three solvents extraction (methanol, ethanol and water) were not detected. The results of Ferric reducing antioxidant power (FRAP), one of the assays used to determine the antioxidant activity are presented in Figure 2. These results showed that FRAP value were higher in methanol extracted samples compared to ethanol extraction for all of three food samples with an undetectable FRAP activity in water extraction. This indicated that methanol extraction was more capability in extracting antioxidant in $\mathrm{MCP}, \mathrm{BMC}$, and $\mathrm{CMC}$ compared to ethanol and water.

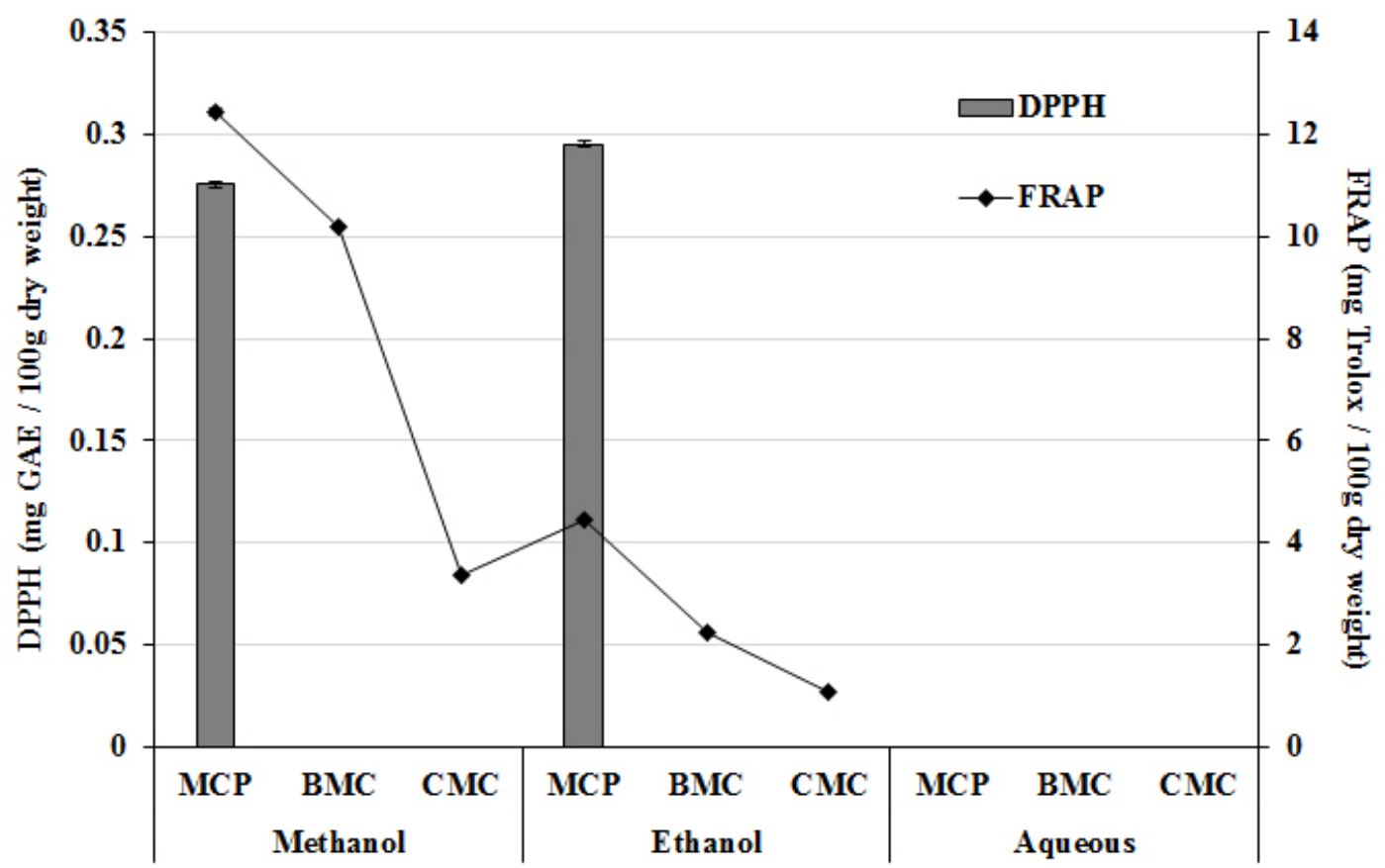

\section{Extract condition}

Figure 2. Antioxidant activity by DPPH radical scavenging activity and ferric reducing antioxidant power (FRAP) of different Thai Massaman curry.

The fact, organic solvents normally exhibit good antioxidant capacity than aqueous solvent has already been reported by Array et al (2007) who demonstrated the antioxidant activity by methanolic and ethanolic extracts of turmeric was significantly higher than that of the aqueous extracts [31]. In this study, MCP extract observed by using a pure organic solvent (methanol and ethanol) gave stronger radical scavenging ability than that of water extract. Nevertheless, aqueous extract both of MCP and CMC undetectable of antioxidant activity using DPPH radical scavenging and FRAP assay. The TFC also not detectable when all samples were extracted by aqueous solution. This might be the nature of active compounds in that samples not be appropriated to dissolve in extraction method of this study.

Antioxidant activity is not necessarily in the same order as TPC or TFC indicating that high TPC or TFC do not always mean high antioxidant capacity and vice versa. However, the current study revealed that the highest antioxidant activity of MCP in DPPH radical scavenging and FRAP assay were highest in methanol and ethanol extracts. In addition to radical scavenging, polyphenols are also known as metal chelators. Chelation of transition 
metals such as $\mathrm{Fe}^{2+}$ can directly reduce the rate of Fenton reaction, thus preventing oxidation caused by highly reactive hydroxyl radicals [35, 36]. Polyphenols do not act alone, it has been found that polyphenols can actually function as a co-antioxidant, and are involved in the regeneration of essential vitamins [37]. Siwarungson and Lertpringkop found that Massaman curry paste showed strongly antioxidant activity comparing with red curry, phanang curry and green curry; although it showed activity lower than green curry [38]. These authors reported that the descending ability of antioxidant properties as followed; green curry > Massaman Curry> red curry> Phanang curry.

\section{Identification of phenolic acids of Massaman curry and their products}

Results of phenolic and flavonoid compounds in MCP, BMC, and CMC by HPLC method are presented in Table 3. The main phenolic acid in these samples is ferulic acid which was the highest content in methanol extracted, followed by ethanol then water extraction. Moreover, syringic acid, chlorogenic acid and coumaric acid were also found in a high content in methanol extract of MCP. Various bioactive compounds are derived from Massaman curry paste and their products, including, vanillic acid, cinnamic acid, gallic acid, and catechin. Altogether, these results suggest that ferulic acid was high content in MCP and in cooked Massaman curry extracted.

\begin{tabular}{|l|c|c|c|c|c|c|c|c|c|}
\hline \multirow{2}{*}{$\begin{array}{l}\text { Phenolic } \\
\text { compounds }\end{array}$} & \multicolumn{3}{|c|}{ Methanol } & \multicolumn{3}{c|}{ Ethanol } & \multicolumn{3}{c|}{ Aqueous } \\
\cline { 2 - 11 } & MCP & BMC & CMC & MCP & BMC & CMC & MCP & BMC & CMC \\
\hline Gallic acid & + & ++ & ++ & + & + & + & + & + & + \\
\hline Protocatchuie & - & - & - & - & - & - & - & - & - \\
\hline Catechin & - & ++ & +++ & - & - & + & ++ & + & + \\
\hline Chlrogenic acid & ++ & +++ & +++ & + & - & - & ++ & - & - \\
\hline Caffeic & - & - & - & - & - & - & - & - & - \\
\hline Syringic acid & +++ & ++ & ++ & + & - & - & - & - & - \\
\hline Vanillic acid & ++ & + & + & - & + & + & - & - & - \\
\hline Coumaric & ++ & ++ & ++ & ++ & ++ & ++ & + & + & + \\
\hline Ferulic & +++ & +++ & +++ & ++++ & +++ & +++ & + & + & + \\
\hline Rutin & - & - & - & - & - & - & - & - & - \\
\hline cinnamic acid & ++ & + & + & ++ & ++ & ++ & ++ & ++ & ++ \\
\hline
\end{tabular}

(+) presence low values contents (less than $10 \mathrm{mg} / 100 \mathrm{~g}$ dry crude extracts), $(++)$ presence medium values contents $(10-50 \mathrm{mg} / 100 \mathrm{~g}$ dry crude extracts), (+++) presence moderate-high values contents $(50-100 \mathrm{mg} / 100 \mathrm{~g}$ dry crude extracts), (++++) presence high values contents $(>100 \mathrm{mg} / 100 \mathrm{~g}$ dry crude extracts), and $(-)=$ absence. Each value was obtained by calculating the average of two experiments. Massaman Curry Paste (MCP); Beef Massaman Curry (BMC) and Chicken Massaman Curry (CMC). 
Ferulic acid, a ubiquitous natural phenolic phytochemical present in seeds and leaves, both in its free and covalently conjugated form in the cell wall of several plants [39]. It is insoluble in water at room temperature but soluble in hot water, ethyl acetate, ethanol, and ethyl ether, and has been found that ethanol (60\%) is suitable for the successful extraction of ferulic acid [40]. Therefore, this study found low content of ferulic acid in water extracted.

In ready-to-eat Massaman curry, coconut milk is one of the main ingredients, it rich in nutrients and phytochemical such as protein, fatty acid and phenolic compounds [41] and has exhibited antioxidant effects [42]. It is also rich in the phenolic compounds such as $\rho$ coumaric acid, ellagic acid and ferulic acid [41]. Gallic acid and coumaric acid normally are found in onion, cumin, nutmeg, fennel, and peppermint [43]. This study found that all samples contain gallic acid, coumaric acid, ferulic acid and cinnamic acid.

It is clear that each spices or herbs employed in Thai foods supplies antioxidants to some extent. However, the influence of the mixture and cooking process, especially in ready-to-eat in whole dish on antioxidant properties and phenolic contents in Asian foods was limited in the literature. There are a few reports on antioxidant activity, phenolic and flavonoids contents in the cooked foods [44]. These results showed that Thai curry paste like Massaman curry and their food products can show amount of active compound with potential antioxidant activity. Therefore, Thai food may be able to delay or prevent the onset of antioxidant health-related disease.

\section{CONCLUSION}

Massaman is one of the most popular Thai curries. It is a mild coconut milk-based soup containing high nutritive value. MCP extract showed the highest of carbohydrate ash and moisture content, and for extract in methanol and demonstrated higher TPC than the ethanol and aqueous solution. Methanol extract is the highest antioxidant both in DPPH radical scavenging activity and FRAP assay and also gave the highest content of TFC. Moreover, various types of phenolic acid compound were detected including gallic acid, coumaric acid, and cinnamic acid. This study showed that Massamun curry paste both fresh and cooked also provide antioxidant capacity derived from various herbs and spices used as ingredients. The results suggest that the health benefits from these plants source still remained in the products after being cooked.

List of Abbreviations: $\mathrm{AlCl}_{3}$, Aluminium chloride; ANOVA, Analysis of variance; AOAC, Association of Official Analytical Chemists; BMC, Beef Massaman curry; CE, Catechin equivalent; CMC, Chicken Massaman curry; DPPH, 2,2-dyphenyl-1-picrylhydrazyl; $\mathrm{FeCl}_{3}$, Ferric Chloride; FRAP, Ferric Reducing Antioxidant Power; GAE, Gallic acid equivalent; HPLC, High performance liquid chromatography; MCP, Massaman curry paste; $\mathrm{Na}_{2} \mathrm{CO}_{3}$, Sodium carbonate; $\mathrm{NaOH}$, Sodium Hydroxide; $\mathrm{NaNO}_{2}$, Sodium nitrite; ND, Non detected; SD, Standard deviation; TFC, Total flavonoid content; TPC, total phenolic content; TPTZ, 2, 4, 6-tripyridyl-s-triazine.

Competing Interests: The authors declare that there is no conflict of interest.

Author's Contributions: All authors contributed to these studies. 
Acknowledgements and Funding: This work was financially supported from Government Budget Grant (PHY610103S), Prince of Songkla University, Hat Yai, Songkhla, Thailand.

\section{REFERENCES}

1. Sirisunthorn S: Thai food culture from past to present. 2nd edition. Bangkok: WVO Office of Printing Mill, The War Veterans Organization of Thailand Under Royal Patronage of His Majesty the King; 2013.

2. Kotsaeng N, Nakornriab M: Total phenolic contents and antioxidant activity of some fresh Thai curry. Int J Geomate 2016, 11(28): 2906-2909.

3. 40 Thai foods we can't live without [http://edition.cnn.com/travel/ article/bangkok-food-thai-dishes/index.html] Retrieved July 30, 2017.

4. Nishimura H, Takahashi T, Wijaya $\mathrm{CH}$, Satoh A, Ariga T: Themochemical transformation of sulfur compounds in Japanese domestic Allium, Allium victorialis L. Biofactors 2000, 13(1-4): 257-263.

5. Shelef LA: Antimicrobial effects of spices. J Food Safety 1984, 6: 29-44.

6. Siripongvutikorn S, Thummaratwasik P, Huang YW: Antimicrobial and antioxidation effects of Thai seasoning, Tom-Yum. Lebensm Wiss Technol 2005, 38(4): 347-352.

7. Sotto AD, Vecchiato M, Abete L, Toniolo C, Giusti AM, Mannina L, Locatelli M, et al.: Capsicum annuum L. var. Cornetto di Pontecorvo PDO: Polyphenolic profile and in vitro biological activities. J Funct Foods 2018, 40: 679-691.

8. Ravindran PN, Balachandran I: Galangal. In Handbook of Herbs and Spices. Volume 3. 1st edition. Edited by Peter KV. Cambridge, England: Woodhead Publishing Limited; 2006:357-364.

9. Wei JN, Liu ZH, Zhao YP, Zhao LL, Xue TK, Lan QK: Phytochemical and bioactive profile of Coriandrum sativum L. Food Chem 2019, 286:260-267.

10. Hamidpour R, Hamidpour M, Hamidpour S, Shahlari M: Cinnamon from the selection of traditional applications to its novel effects on the inhibition of angiogenesis in cancer cells and prevention of Alzheimer's disease, and a series of functions such as antioxidant, anticholesterol, antidiabetes, antibacterial, antifungal, nematicidal, acaracidal, and repellent activities. Journal of Traditional and Complementary Medicine 2015, 5(2):66-70.

11. Hellon J: The Blue Elephant Cookbook: Royal Thai Cuisine. London: Pavilion Books; 1999.

12. Association of Official Analytical Chemists (AOAC): Official Methods of Analysis. 17th Edition. The Association of Official Analytical Chemists: Gaithersburg, MD, USA; 2000.

13. Department of Medical Science (DMSc) and National Bureau of Agricultural Commodity and Food Standards (ACFS): Fatty acid in food gas-liquid chromatography method. In Compendium of methods for food analysis. 1st edition. Thailand: Bangkok; 2003.

14. Do QD, Angkawijaya AE, Tran-Nguyen PL, Huynh LH, Soetaredjo FE, Ismadji S, Ju YH: Effect of extraction solvent on total phenol content, total flavonoid 
content, and antioxidant activity of Limnophila aromatica. J Food Drug Anal 2014, 22(3):296-302.

15. Slinkard K, Singleton VL: Total phenol analysis: Automation and comparison with manual methods. Am J Enol Vitic 1977, 28:49-55.

16. Zhishen J, Mengcheng T, Jianming W: The determination of flavonoid contents in mulberry and their scavenging effects on superoxide radicals. Food Chem 1999, 64(4):555-559.

17. Brand-Williams W, Cuvelier ME, Berset C: Use of a free radical method to evaluate antioxidant activity. Food Sci Technol 1995, 28(1):25-30.

18. Benzie IF, Strain JJ: The ferric reducing ability of plasma (FRAP) as a measure of "antioxidant power": the FRAP assay. Anal Biochem 1996, 239(1):70-76.

19. Prangthip P, Charoenkiatkul S, Kettawan A, Okuno M, Okamoto T: Thai red curry paste lowers glucose, oxidative stress and insulin levels in type II diabetic rats. Int Food Res J 2012, 19(2):623-627.

20. Carreiro AL, Dhillon J, Gordon S, Higgins KA, Jacobs AG, McArthur BM, Redan BW, et al.: The macronutrients, appetite, and energy intake. Annu Rev Nutr 2016, 36:73-103.

21. Raghavendra SN, Raghavarao KSMS: Effect of different treatments for the destabilization of coconut milk emulsion. J Food Eng 2010, 97(3):341-347.

22. Sapabguy C, Yasurin P: Natural Antibacterial Activity of Thai Red Curry Paste in Coconut Milk Based Curry; Kang-Kati, Model on Salmonella sp. and Listeria monocytogenes. Walailak J Sci and Tech 2015, 12:473-480.

23. Teres S, Barcelo-Coblijn G, Benet M, Alvarez R, Bressani R, Halver JE, Escriba $\mathrm{PV}$ : Oleic acid content is responsible for the reduction in blood pressure induced by olive oil. PNAS 2008, 105(37):13811-13816.

24. Jandacek RJ: Linoleic acid: A nutritional quandary. Healthcare (Basel) 2017, 5(2):pii:E25.

25. Rajaram S: Health benefits of plant derived $\alpha$-linolenic acid. Am J Clin Nutr 2014, 100(suppl 1):443S-448S.

26. Simopoulos AP: Essential fatty acids in health and chronic disease. Am J Clin Nutr 1999, 70:560-569.

27. Perera SBST, Jayasinghe GDTM, De Silva MSW, Jinadasa BKKK: Fatty acid composition of three different marine fish under different culinary process. JNFSF 2019, 2:1-4.

28. Jarret RL, Levy IJ, Potter TL, Cermak SC: Seed oil and fatty acid composition in Capsicum spp. J Food Compos Anal 2013, 30(2):102-108.

29. Stalikas CD: Extraction, separation, and detection methods for phenolic acids and flavonoids. J Sep Sci 2007, 30(18):3268-3295.

30. Do QD, Angkawijaya AE, Tran-Nguyen PL, Huynh LH, Soetaredjo FE, Ismadji $\mathrm{S}$, Ju YH: Effect of extraction solvent on total phenol content, total flavonoid content, and antioxidant activity of Limnophila aromatica. J Food Drug Anal 2014, 22(3):296-302.

31. Array EJ, Djikeng TF, Kingne KF, Kinge EE, Womeni H: Effect of different extraction solvents on the phenolic content and antioxidant activity of turmeric 
(Curcuma longa) from South-West Region, Cameroon. Food Research 2019, 3(1):86-90.

32. Settharaksa S, Madaka F, Sueree L, Kittiwisut S, Sakunpak A, Moton C, Charoenchai L: Effect of solvents types on phenolic, flavonoid contents and antioxidant activities of Syzygium Gratum (Wight) S.N. Int J Pharm Pharm Sci 2014, 6(2):114-116.

33. Turkmen N, Sari F, Velioglu YS: Effects of extraction solvents on concentration and antioxidant activity of black and black mate tea polyphenols determined by ferrous tartrate and Foline-Ciocalteu methods. Food Chem 2006, 99(4):835-841.

34. Sepahpour S, Selamat J, Manap MYA, Khatib A, Razis AFA: Comparative analysis of chemical composition, antioxidant activity and quantitative characterization of some phenolic compounds in selected herbs and spices in different solvent extraction systems. Molecules 2018, 23(2):402.

35. Pietta PG: Flavonoids as antioxidants. J Nat Prod 2000, 63(7):1035-1042.

36. Perron NR, Brumaghim JL: A review of the antioxidant mechanisms of polyphenol compounds related to iron binding. Cell Biochem Biophys 2009, 53(2):75-100.

37. Zhou B, Wu LM, Yang L, Liu ZL: Evidence for alpha-tocopherol regeneration reaction of green tea polyphenols in SDS micelles. Free Radic Biol Med 2005, 38(1):78-84.

38. Siwarungson N, Lertpringkop P, Gupta S: Comparison of antioxidant and antiaging activities in selected Thai curry paste and dishes using water extraction and simulation of gastrointestinal digestion in vitro experiments. Int J Food Sci Nutr 2016, 1:6-9.

39. Kumar N, Pruthi V: Potential applications of ferulic acid from natural sources. Biotechnol Rep (Amst) 2014, 4:86-93.

40. Guo T, Sun Y, Sui Y, Li F: Determination of ferulic acid and adenosine in Angelicae radix by micellar electrokinetic chromatography. Anal Bioanal Chem 2003, 375(6):840-843.

41. Nadeeshani R, Wijayaratna U, Prasadani WC, Ekanayake S, Seneviratne K, Jayathilaka N: Comparison of the basic nutritional characteristics of the first extract and second extract of coconut milk. Int J Innov Res Sci Eng Technol 2015, 4: 9516-9521.

42. Alyaqoubi S, Abdullah A, Samudi M, Abdullah N, Addai ZR, Musa KH: Study of antioxidant activity and physicochemical properties of coconut milk (Pati Santan) in Malaysia. J Chem Pharm Res 2015, 7(4): 967-973.

43. Yashin A, Yashin Y, Xia X, Nemzer B: Antioxidant activity of spices and their impact on human health: A review. Antioxidants (Basel) 2017, 6(3):pii:E70.

44. Tangkanakul P, Auttaviboonkul P, Niyomwit B, Lowvitoon N, Charoenthamawat P, Trakoontivakkorn G: Antioxidant capacity, total phenolic content and nutritional composition of Asian foods after thermal processing. Int Food Res J 2009, 16:571-580. 